\title{
Detection of Human Urinary 5-Hydroxymethylcytosine by Stable Isotope Dilution HPLC-MS/MS Analysis
}

\author{
Ruichuan Yin, ${ }^{\dagger}$ Jiezhen Mo, $^{\dagger}$ Meiling Lu, ${ }^{\ddagger}$ and Hailin Wang*, ${ }^{\dagger}$ \\ ${ }^{\dagger}$ State Key Laboratory of Environmental Chemistry and Ecotoxicology, Research Center for Eco-Environmental Sciences, Chinese \\ Academy of Sciences, Beijing 100085, China \\ ${ }^{\ddagger}$ Chemical Analysis Group, Agilent Technologies, Beijing 100102, China
}

\begin{abstract}
The sixth DNA base 5-hydroxymethylcytosine $(5 \mathrm{hmC})$ is the major oxidation product of the epigenetic modification 5-methylcytosine $(5 \mathrm{mC})$, mediating DNA demethylation in mammals. Reduced $5 \mathrm{hmC}$ levels are found to be linked with various tumors and neurological diseases; therefore, $5 \mathrm{hmC}$ is an emerging biomarker for disease diagnosis, treatment, and prognosis. Due to its advantages of being sterile, easily accessible in large volumes, and noninvasive to patients, urine is a favored diagnostic biofluid for $5 \mathrm{hmC}$ analysis. Here we developed an accurate, sensitive, and specific assay for quantification of $5 \mathrm{mC}, 5 \mathrm{hmC}$, and other DNA demethylation intermediates in human urine. The urinary samples were desalted and enriched using off-line solid-phase extraction, followed by stable isotope dilution HPLC-MS/MS analysis for $5 \mathrm{hmC}$ and $5 \mathrm{mC}$. By the use of ammonium bicarbonate $\left(\mathrm{NH}_{4} \mathrm{HCO}_{3}\right)$ as an additive to the mobile phase, we improved the online-coupled MS/MS detection of $5 \mathrm{mC}, 5 \mathrm{hmC}$, and 5-formylcytosine (5fC) by $1.8-14.3$ times. The recovery of the method is approximately $100 \%$ for $5 \mathrm{hmC}$, and $70-90 \%$ for $5 \mathrm{mC}$. The relative standard deviation (RSD) of the interday precision is about $2.9-10.6 \%$, and that of the intraday precision is about $1.4-7.7 \%$. By the analysis of 13 volunteers using the developed method, we for the first time demonstrate the presence of $5 \mathrm{hmC}$ in human urine. Unexpectedly, we observed that the level of $5 \mathrm{hmC}(22.6 \pm 13.7 \mathrm{nmol} / \mathrm{L})$ is comparable to that of its precursor $5 \mathrm{mC}(52.4 \pm 50.2 \mathrm{nmol} / \mathrm{L})$ in human urine. Since the abundance of $5 \mathrm{hmC}$ (as a rare DNA base) is 1 or 2 orders of magnitude lower than $5 \mathrm{mC}$ in genomic DNA, our finding probably implicates a much higher turnover of $5 \mathrm{hmC}$ than $5 \mathrm{mC}$ in mammalian genomic DNA and underscores the importance of DNA demethylation in daily life.
\end{abstract}

$\mathrm{T}$ he well-characterized epigenetic modification 5-methylcytosine $(5 \mathrm{mC})$ plays important roles in regulation of gene expression, ${ }^{1-3}$ genomic imprinting, ${ }^{4}$ and $\mathrm{X}$-chromosome inactivation. ${ }^{5,6}$ Recently, $5 \mathrm{mC}$ was found to be oxidized by Tet (ten eleven translocation) family dioxygenases to form 5hydroxymethylcytosine $(5 \mathrm{hmC})$ in mammals. ${ }^{7,8}$ As the "sixth" DNA base, $5 \mathrm{hmC}$ is involved in a variety of physiological processes, e.g., DNA demethylation, ${ }^{9,10}$ somatic cell reprogramming, ${ }^{11}$ and embryonic development. ${ }^{12-14}$ Recently, our group and other laboratories discovered that some nutrient or environmental factors (vitamin $\mathrm{C}^{15}$ redox-active quinones, ${ }^{16}$ heavy metals ${ }^{17}$ ) can alter the genome-wide distribution of $5 \mathrm{hmC}$ in the mammalian genome. It is also noted that the level of $5 \mathrm{hmC}$ significantly decreases in various cancers, ${ }^{18-23}$ including the tumors of lung, brain, liver, kidney, skin, small intestine, prostate, breast, and colon, melanomas, and hepatocellular carcinomas, suggesting that $5 \mathrm{hmC}$ plays an important role in cancer development. ${ }^{22-25}$ In addition, aberrant $5 \mathrm{hmC}$ distribution has also been found in myelodysplastic syndrome, ${ }^{26}$ Huntington's disease, ${ }^{27}$ Alzheimer's disease, $^{28}$ and psychosis. ${ }^{29}$ All of these findings prompt us to propose that $5 \mathrm{hmC}$ is an emerging biomarker for disease diagnosis, treatment, and prognosis.
$5 \mathrm{hmC}$ is present with the highest abundance in brain and at low levels in lung, heart, breast, and spleen. ${ }^{30-34}$ Although $5 \mathrm{hmC}$ levels have been detected in various tissues, information on urinary $5 \mathrm{hmC}$ is lacking. Since it is sterile, easily accessible in large volumes, and noninvasive to patients, urine has long been considered as a favored diagnostic biofluid in clinical practice. Therefore, urinary $5 \mathrm{hmC}$ analysis should be a first choice for clinical diagnosis, disease treatment, and prognosis. Compared with tissue $5 \mathrm{hmC}$ analysis, urinary $5 \mathrm{hmC}$ analysis does not require genomic DNA extraction and digestion. Several biological processes (e.g., apoptosis, erythropoiesis, and lens cell development ${ }^{35-37}$ ) can cause DNA degradation into deoxynucleosides. Therefore, it is reasonable to believe that DNA degradation or metabolism-caused $5 \mathrm{hmC}$ in the form of single deoxynucleosides could be excreted into urine through the circulation system. In fact, the $5 \mathrm{hmC}$ precursor $5 \mathrm{mC}$ was successfully identified and quantified in human urine. ${ }^{38-42}$

A number of specific technologies for tissue $5 \mathrm{hmC}$ analysis have been developed, including thin layer chromatography

Received: October 17, 2014

Accepted: December 31, 2014

Published: December 31, 2014 
(TLC) $-{ }^{32} \mathrm{P}$ labeling, ${ }^{7,25,43}$ immunoassays, ${ }^{24,25,31,44}$ and liquid chromatography-mass spectrometry (LC-MS). ${ }^{15,16,32,33,45-50}$ TLC $-{ }^{32} \mathrm{P}$ labeling method is very sensitive due to the use of radioactive ${ }^{32} \mathrm{P}$ labeling, but this method is limited to the determination of $5 \mathrm{hmC}$ in restriction enzyme-dependent DNA sequences and requires special safety settings. Immunoassays using antibodies against $5 \mathrm{hmC}^{44}$ or cytosine 5-methylenesulfonate ${ }^{24}$ have been used to specifically detect $5 \mathrm{hmC}$ in genomic DNA without the need for DNA digestion. Compared with the above two methods, LC-MS/MS is of interest due to its advantages in sensitivity, specificity, and structural characterization. ${ }^{45,46}$ However, the ionization efficiency of $5 \mathrm{mC}$ and its oxidation products is poor, and the corresponding sensitivity of LC-MS/MS analysis is unsatisfactory. To improve LC-MS/MS analysis, one solution is to use hydrophilic-interaction liquid chromatography (HILIC), by which organic solvents of high concentration can be exploited to promote solvent evaporation and protonation of the analytes during electrospray ionization. ${ }^{47,48}$ HILIC can also be used to enrich glucosylated $5 \mathrm{hmC} .{ }^{49}$ To the best of our knowledge, no methods have been reported so far for the detection of $5 \mathrm{mC}$ oxidation products (including free $5 \mathrm{hmC}$ nucleosides) in human urine.

In this work, we describe in detail an enhanced ionization method specifically for detection of $5 \mathrm{mC}$ and DNA demethylation intermediates (Scheme 1). Moreover, we

Scheme 1. Possible Pathways of Tet-Mediated Active DNA Demethylation

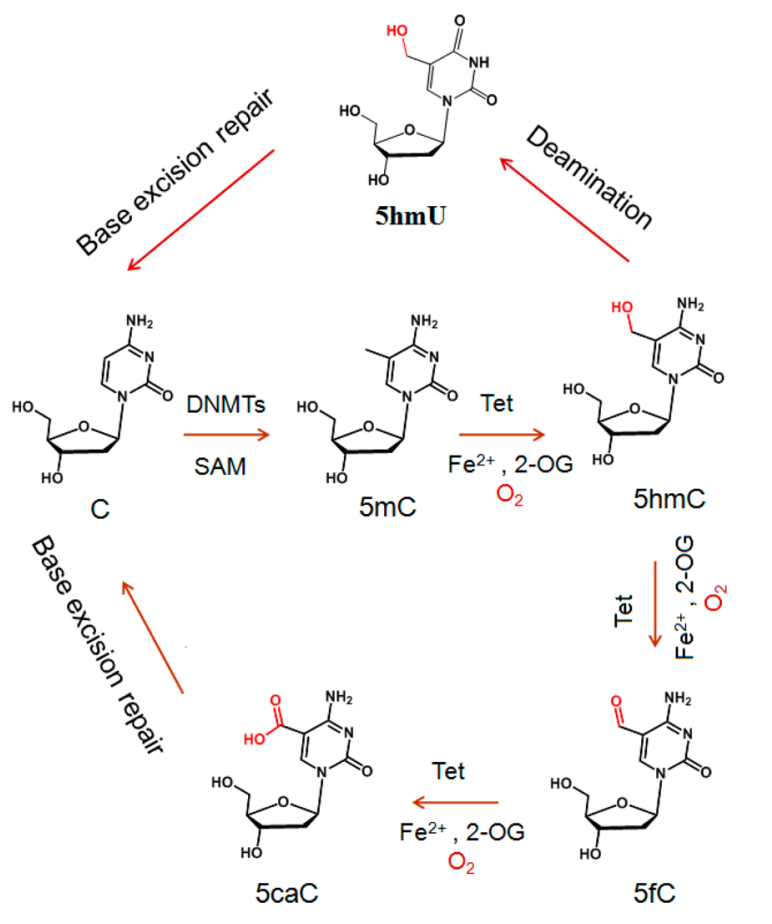

developed a solid-phase extraction (SPE) approach for desalting and enriching the nucleosides from human urine. By off-line coupling of SPE with stable isotope dilution HPLCMS/MS, we developed an approach for accurate determination of $5 \mathrm{mC}$ and $5 \mathrm{hmC}$ in human urine. By the developed approach, we for the first time demonstrate the presence and the abundance of $5 \mathrm{hmC}$ in human urine.

\section{EXPERIMENTAL SECTION}

Chemicals. $5 \mathrm{hmC}, 5 \mathrm{fC}$, and $5 \mathrm{mC}$ were obtained from Berry \& Associates (Dexter, MI). $5 \mathrm{caC}$ and $5 \mathrm{hmU}$ were gifts from Dr. Guoliang $\mathrm{Xu}$ at the Institute of Biochemistry and Cell Biology, Chinese Academy of Sciences. 5-Hydroxymethylcytosine- $d_{3}-2$ deoxycytidine $\left(\left[\mathrm{D}_{3}\right] 5 \mathrm{hmC}\right)$ and 5-methyl- $d_{3}$-2-deoxycytidine $\left(\left[\mathrm{D}_{3}\right] 5 \mathrm{mC}\right)$ were purchased from Toronto Chemical Research (Toronto, Canada). Formic acid $(\mathrm{HCOOH})$ and ammonium acetate $\left(\mathrm{CH}_{3} \mathrm{COONH}_{4}\right)$ were ordered from Acros Organics (Geel, Belgium) and Sinopharm Chemical Reagent Co. (Beijing, China), respectively. Ammonium formate $\left(\mathrm{HCOONH}_{4}\right)$ and $\mathrm{NH}_{4} \mathrm{HCO}_{3}$ were purchased from SigmaAldrich (St Louis, MO).

HPLC-MS/MS Analysis. The HPLC-MS/MS analysis was performed on an Agilent 1290 UHPLC system coupled with an ESI-triple quadrupole mass spectrometer (G6410B or G6495, Agilent Technologies, Santa Clara, CA). A NUCLEOSHELL $\mathrm{RP} 18$ column $(2.0 \times 100 \mathrm{~mm}, 2.7 \mu \mathrm{m}$ particle size, MachereyNagel, Düren, Germany) was employed for separation of single deoxynucleosides. The mobile phase consisted of two solvents: $2.0 \mathrm{mM} \mathrm{NH}_{4} \mathrm{HCO}_{3}, \mathrm{pH} 8.5$, in water (A), and $100 \%$ methanol (B). The deoxynucleosides were separated with an optimized gradient elution: $0-5.0 \mathrm{~min}, 5 \% \mathrm{~B}$; $5.0-8.0 \mathrm{~min}, 15 \% \mathrm{~B}$; $8.0-$ $12.0 \mathrm{~min}, 100 \% \mathrm{~B} ; 12.0-18.0 \mathrm{~min}, 5 \% \mathrm{~B}$. The flow-rate was $0.25 \mathrm{~mL} / \mathrm{min}$. To optimize the MS detection of deoxynucleosides, four volatile additives to the mobile phase were tested, including $\mathrm{HCOOH}, \mathrm{HCOONH}_{4}, \mathrm{NH}_{4} \mathrm{HCO}_{3}$, and $\mathrm{CH}_{3} \mathrm{COONH}_{4}$.

The mass spectrometer was operated under positive ionization mode with electrospray voltage (capillary voltage) of $3500 \mathrm{~V}$. The molecular ions of $5 \mathrm{mC}, 5 \mathrm{hmC}, 5 \mathrm{fC}, 5 \mathrm{caC}$, and $5 \mathrm{hmU}$ prefer to lose the deoxyribose moiety (MW: $116 \mathrm{Da}$ ) in the process of collision-induced dissociation. Thus, multiple reaction monitoring $(\mathrm{MRM})$ transitions of $[\mathrm{M}+\mathrm{H}]^{+} \rightarrow[\mathrm{M}+$ $\mathrm{H}-116]^{+}$were chosen to quantify the tested deoxynucleosides: $m / z 242 \rightarrow 126$ for $5 \mathrm{mC}$ (collision energy, $5 \mathrm{eV}$ ); $m / z$ $245 \rightarrow 129$ for $\left[\mathrm{D}_{3}\right] 5 \mathrm{mC}(5 \mathrm{eV}) ; m / z 258 \rightarrow 142$ for $5 \mathrm{hmC}(5$ $\mathrm{eV}) ; m / z 261 \rightarrow 145$ for $\left[\mathrm{D}_{3}\right] 5 \mathrm{hmC}(5 \mathrm{eV}) ; m / z 256 \rightarrow 140$ for $5 \mathrm{fC}(5 \mathrm{eV}) ; \mathrm{m} / z 272 \rightarrow 156$ for $5 \mathrm{caC}(5 \mathrm{eV}) ; \mathrm{m} / z 259 \rightarrow$ 143 for $5 \mathrm{hmU}(5 \mathrm{eV})$. Those daughter ions with the second highest intensities were used as qualitative ions: $\mathrm{m} / z 242 \rightarrow$ 109 for $5 \mathrm{mC}(30 \mathrm{eV}) ; m / z 258 \rightarrow 124$ for $5 \mathrm{hmC}(30 \mathrm{eV})$. The fragmentation voltage for all the MRM transitions were set at $90 \mathrm{~V}$ to allow efficient transit of precursor ions. Nitrogen gas was used for nebulization and desolvation. The nebulization gas pressure was set at $40 \mathrm{psi}$, and the temperature and the flow rate of desolvation gas were set at $300{ }^{\circ} \mathrm{C}$ and $9.0 \mathrm{~L} / \mathrm{min}$, respectively. High purity nitrogen (99.999\%) was used as collision gas. Each sample was analyzed at least three times with an injection volume of $5.0 \mu \mathrm{L}$.

Solid-Phase Extraction. To obtain satisfactory extraction efficiency, two types of SPE cartridges (C18 and HLB) were first tested using HPLC-UV analysis. The C18 and HLB cartridges with equal amounts of packing $(6.0 \mathrm{~mL}, 500 \mathrm{mg}$ per cartridge) were purchased from Agela Technologies (Tianjin, China) and Waters Corporation (Milford, MA), respectively. Each cartridge was first preconditioned with $10.0 \mathrm{~mL}$ of methanol followed by $6.0 \mathrm{~mL}$ of water. Then a $1.0 \mathrm{~mL}$ premixed dexoynucleoside standard solution (final concentration of each deoxynucleoside: $1.0 \mu \mathrm{M}$ ) was loaded into the preconditioned cartridges. The cartridges were washed with 5.0 $\mathrm{mL}$ of $\mathrm{H}_{2} \mathrm{O}$ and successively eluted with $5.0 \mathrm{~mL}$ of methanol/ 




\begin{tabular}{|c|c|c|c|}
\hline $\begin{array}{c}\text { area ratios } \\
\text { additives }\end{array}$ & $5 \mathrm{hmC}$ & $5 \mathrm{mC}$ & $5 \mathrm{fC}$ \\
\hline $\mathrm{NH}_{4} \mathrm{HCO}_{3}$ & 4.8 & 4.1 & 5.7 \\
\hline $\mathrm{CH}_{3} \mathrm{COONH}_{4}$ & 1.3 & 2.3 & $\mathbf{2 . 0}$ \\
\hline $\mathrm{HCOONH}_{4}$ & $\mathbf{0 . 4}$ & $\mathbf{0 . 9}$ & 0.4 \\
\hline $\mathrm{HCOOH}$ & 1.0 & 1.0 & 1.0 \\
\hline
\end{tabular}

Figure 1. Effect of mobile-phase additives on the HPLC separation and MS detection sensitivity of $5 \mathrm{mC}$, $5 \mathrm{hmC}$, and $5 \mathrm{fC}$. Left panel represents typical chromatograms of $5 \mathrm{mC}, 5 \mathrm{hmC}$, and $5 \mathrm{fC}$ that were obtained using four different additives to the mobile phase. The peak area ratios of the target analytes obtained by ammonium salt vs $\mathrm{HCOOH}$ are summarized in the table to the right. The mobile phase consisted of solvents $\mathrm{A}$ and $\mathrm{B}$ (pure methanol). Solvent A was $2.0 \mathrm{mM}$ ammonium salt $\left(\mathrm{HCOONH}_{4}, \mathrm{CH}_{3} \mathrm{COONH}_{4}\right.$, and $\left.\mathrm{NH}_{4} \mathrm{HCO}_{3}\right)$ or $0.1 \%$ formic acid in water. An isocratic elution of $95 \% \mathrm{~A}$ and $5 \% \mathrm{~B}$ was used, and the flow was set at $0.25 \mathrm{~mL} / \mathrm{min}$. The final concentrations of $5 \mathrm{mC}$, $5 \mathrm{hmC}$, and $5 \mathrm{fC}$ standards were $10 \mathrm{nM}$, and the injection volume was $5.0 \mu \mathrm{L}$.

water $1: 9(\mathrm{v} / \mathrm{v})$ and $5.0 \mathrm{~mL}$ of methanol/water 3:7 (v/v). When methanol was removed by nitrogen gas at room temperature, the eluted fractions from each step were frozen at $-80{ }^{\circ} \mathrm{C}$ and then lyophilized at $-50{ }^{\circ} \mathrm{C}$ under a vacuum of $0.01 \mathrm{mbar}$. The residues were centrifuged at $12000 \mathrm{rpm}$ for 10 min and redissolved in $50 \mu \mathrm{L}$ of $\mathrm{H}_{2} \mathrm{O}$.

To evaluate the SPE protocol, the collected SPE fractions were further analyzed using a Shimadzu LC-20AD HPLC system equipped with an SPD-20A UV detector. $5 \mathrm{hmU}, 5 \mathrm{mC}$, and its oxidation products were separated with a Venusil MP C18 column $(4.6 \times 100 \mathrm{~mm}, 5.0 \mu \mathrm{m}$, Agela Technologies, Tianjin, China) using an isocratic elution of methanol/water $(1: 9)$ at $0.8 \mathrm{~mL} / \mathrm{min}$. The detection wavelength was set at 280 $\mathrm{nm}$, and the injection volume was $5.0 \mu \mathrm{L}$.

To fit to HPLC MS/MS analysis, the collected urine samples were also pretreated using solid-phase extraction. However, a smaller HLB cartridge ( $3.0 \mathrm{~mL}, 60 \mathrm{mg}$ per cartridge) was tailored for this application.

Linearity, Accuracy, and Precision. The standard solutions of $5 \mathrm{hmC}$ and $5 \mathrm{mC}$ standards of varying concentrations (2.0, 4.0, 8.0, 16.0, 32.0, and $64.0 \mathrm{nM}$ ) mixed with 80 $\mathrm{nM}\left[\mathrm{D}_{3}\right] 5 \mathrm{hmC}$ and $40 \mathrm{nM}\left[\mathrm{D}_{3}\right] 5 \mathrm{mC}$ (as internal standards) were prepared and then analyzed using the HPLC-MS/MS method described above. Calibration curves were constructed by linearly plotting the peak area ratios of $5 \mathrm{hmC}$ and $5 \mathrm{mC}$ to the corresponding stable isotopic standards against the concentration of the added nonisotopic $5 \mathrm{hmC}$ and $5 \mathrm{mC}$.

To calculate the recovery of the method, known amounts of $5 \mathrm{hmC}$ and $5 \mathrm{mC}$ ( 10 and $20 \mathrm{nM}$ ) were added to the urine samples, respectively. After addition of $40 \mathrm{nM}\left[\mathrm{D}_{3}\right] 5 \mathrm{mC}$ and 80 $\mathrm{nM}\left[\mathrm{D}_{3}\right] 5 \mathrm{hmC}$, each sample was passed through a HLB cartridge $(3.0 \mathrm{~mL}, 60 \mathrm{mg}$ per cartridge) and analyzed by HPLC-MS/MS. The recovery $(R)$ was determined according to the formula shown below.

$$
R=\frac{C_{\text {measured }}-C_{\text {background }}}{C_{\text {added }}} \times 100 \%
$$

$C_{\text {measured }}$ and $C_{\text {background }}$ represent the measured concentrations of $5 \mathrm{hmC}$ or $5 \mathrm{mC}$ in spiked and nonspiked urine samples, respectively; $C_{\text {added }}$ is the added amounts of $5 \mathrm{hmC}$ and $5 \mathrm{mC}$ standards. The intraday and interday precision was estimated by triplicate quantification of $5 \mathrm{hmC}$ and $5 \mathrm{mC}$ in human urine samples (nos. 11-13) per day for three consecutive days.

Collection and Preparation of Human Urine Samples.

The urine samples were collected from 13 healthy and young volunteers (age 23-30, five males and eight females). One female volunteer (no. 1) was pregnant in the 25th week at the time of urine collection. All volunteers were nonsmokers. All collected urine samples were stored at $-80^{\circ} \mathrm{C}$ before they were subjected to any pretreatment and analysis. The samples were fully thawed and centrifuged at $12000 \mathrm{rpm}$ for $5.0 \mathrm{~min}$. The collected urine samples were pretreated using HLB cartridges (3.0 mL, $60 \mathrm{mg}$ per cartridge). Each cartridge was preconditioned with $3.0 \mathrm{~mL}$ of methanol followed by $3.0 \mathrm{~mL}$ of water; then urine samples of $200 \mu \mathrm{L}$, each mixed with $\left[\mathrm{D}_{3}\right] 5 \mathrm{mC}$ of $40 \mathrm{nM}$ (final concentration) and $\left[\mathrm{D}_{3}\right] 5 \mathrm{hmC} 80$ $\mathrm{nM}$ (final concentration), were loaded; the cartridges were washed with $1.0 \mathrm{~mL}$ of $\mathrm{H}_{2} \mathrm{O}$, followed by the final elution using $1.0 \mathrm{~mL}$ of methanol/water of 3:7 (v/v). The eluted fractions were evaporated with nitrogen gas, lyophilized, and redissolved in $200 \mu \mathrm{L}$ of pure $\mathrm{H}_{2} \mathrm{O}$.

\section{RESULT AND DISCUSSION}

Ammonium Bicarbonate Enhances the MS Detection of $5 \mathrm{mC}, 5 \mathrm{hmC}$, and $5 \mathrm{fC}$. Our recent work demonstrates that ammonium bicarbonate can significantly improve the ESI-MS/ MS detection of acrolein-deoxyguanine adducts by suppressing the formation of MS signal-deteriorating metal complexes. ${ }^{51}$ However, we do not know whether ammonium bicarbonate enhances the LC-ESI-MS/MS detection of $5 \mathrm{mC}$ and DNA demethylation intermediates. Here we examined the possibility to improve LC-ESI-MS/MS detection of $5 \mathrm{mC}$ and its oxidation products ( $5 \mathrm{hmC}$ and $5 \mathrm{fC}$ ) using ammonium bicarbonate.

First, we tested four additives to the mobile phase, including ammonium bicarbonate, ammonium acetate, ammonium formate, and formic acid. As shown in the bottom trace of Figure $1,5 \mathrm{hmC}$ migrates out at $1.7 \mathrm{~min}$ and is well separated from $5 \mathrm{mC}(2.6 \mathrm{~min})$ and $5 \mathrm{fC}(5.9 \mathrm{~min})$ by the use of $0.1 \%$ $\mathrm{HCOOH}$ as the additive to the mobile phase. Evidently, for all three tested ammonium salts $(2.0 \mathrm{mM})$, the retentions of $5 \mathrm{hmC}(2.6-2.7 \mathrm{~min}), 5 \mathrm{mC}(4.4-5.1 \mathrm{~min})$, and $5 \mathrm{fC}(7.6 \mathrm{~min})$ 

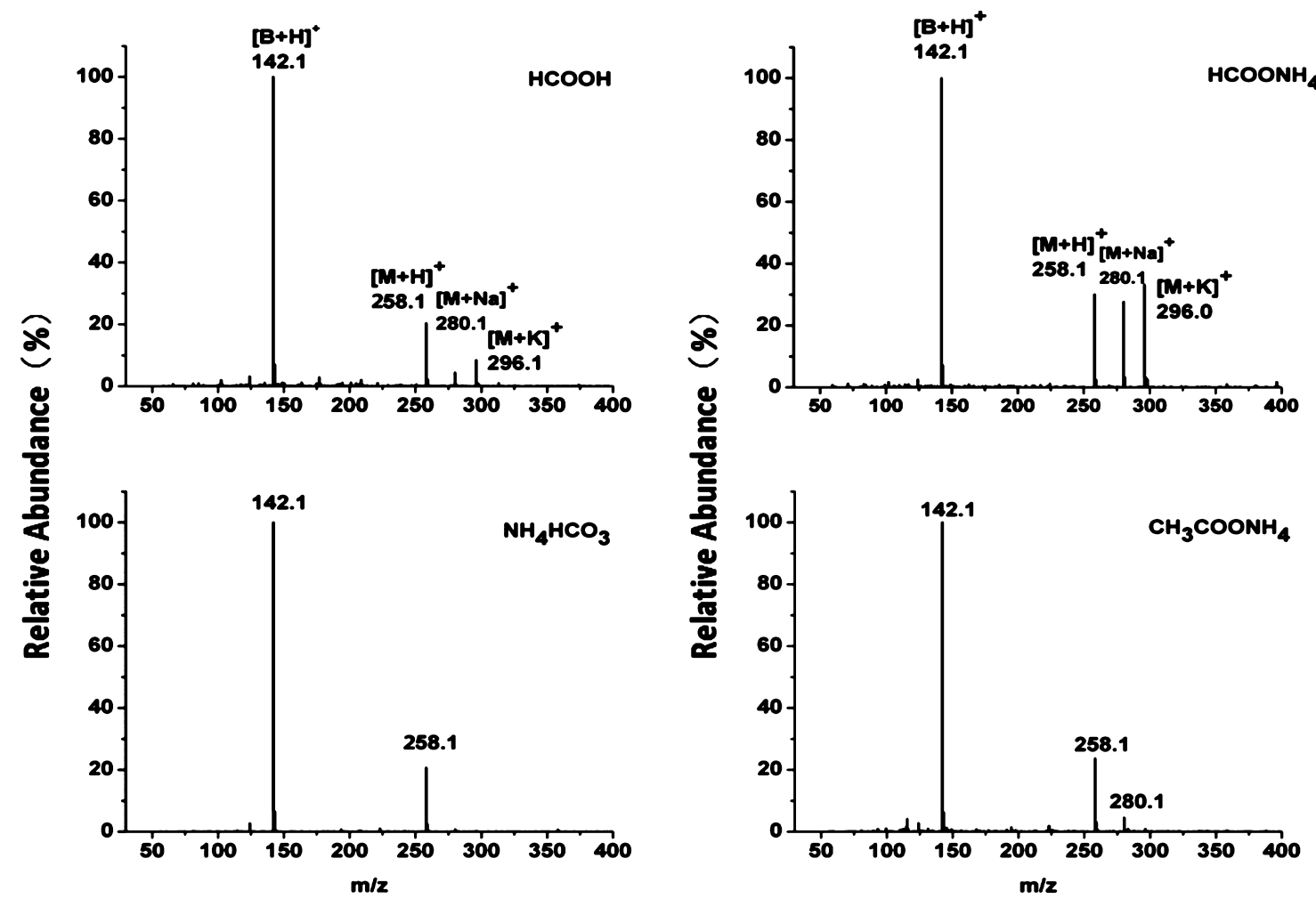

Figure 2. Typical ESI-MS spectra of $5 \mathrm{hmC}$ when four additives were used. An isocratic elution of $95 \% \mathrm{~A}(2.0 \mathrm{mM}$ ammonium salt or $0.1 \%$ formic acid) and $5 \%$ B (pure methanol) was used, and the flow was set at $0.25 \mathrm{~mL} / \mathrm{min}$. A $10 \mu \mathrm{M} 5 \mathrm{hmC}$ standard solution (final concentration) was used, and the injection volume was $5.0 \mu \mathrm{L}$.
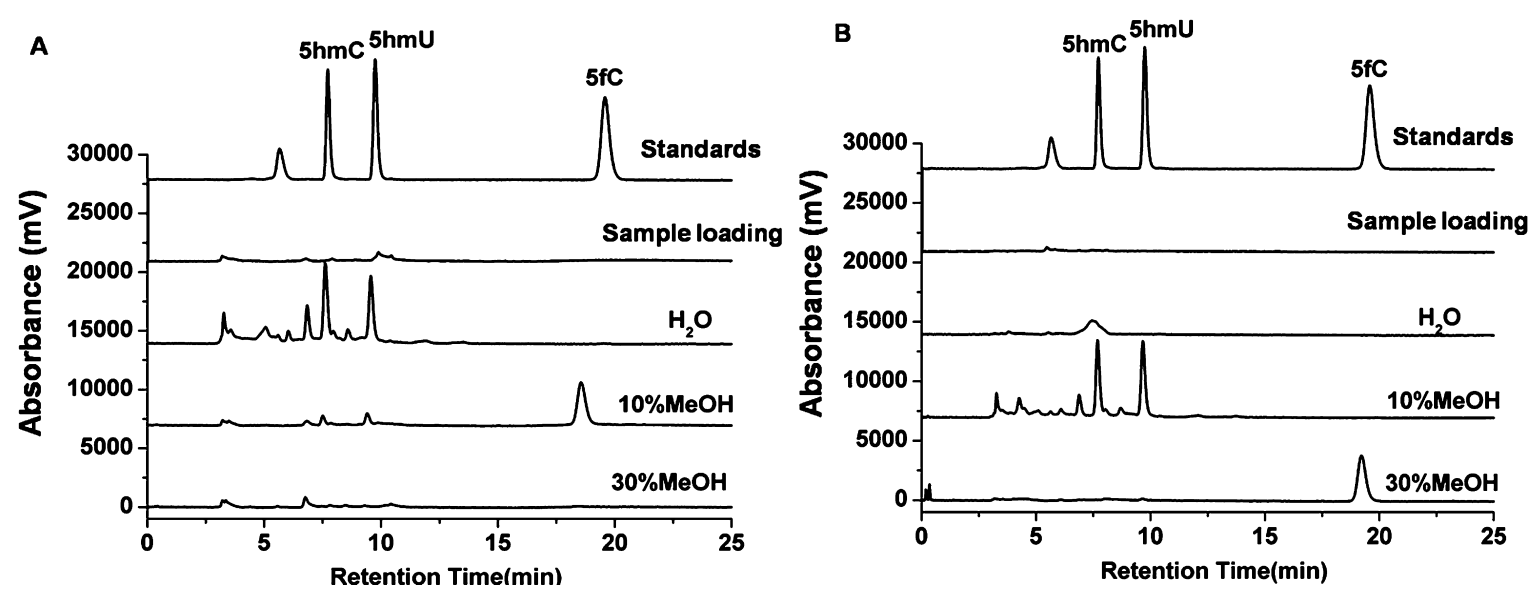

Figure 3. HPLC-UV analysis of each SPE fraction obtained from the mixture of 5hmC, 5hmU, and 5fCs pretreated with C18 (A) and HLB cartridges (B). A $1.0 \mathrm{~mL}$ premixed solution (final concentration of each deoxynucleoside: $1.0 \mu \mathrm{M}$ ) was loaded into the preconditioned cartridges. Each SPE fraction was lyophilized and redissolved in $50 \mu \mathrm{L}$ of $\mathrm{H}_{2} \mathrm{O}$. The concentrations of $5 \mathrm{hmC}, 5 \mathrm{hmU}$, and $5 \mathrm{fC}$ standards were $20 \mu \mathrm{M}$. The injection volume was $5.0 \mu \mathrm{L}$.

increase. More importantly, compared with other three additives $\left(\mathrm{HCOOH}, \mathrm{HCOONH}_{4}\right.$, and $\left.\mathrm{CH}_{3} \mathrm{COONH}_{4}\right)$, $\mathrm{NH}_{4} \mathrm{HCO}_{3}$ increased the $\mathrm{MS} / \mathrm{MS}$ signals of $5 \mathrm{mC}, 5 \mathrm{hmC}$, and 5fC by 1.8-14.3 times (right panel, Figure 1). However, the MS intensity of $5 \mathrm{caC}$ and $5 \mathrm{hmU}$ (data not shown) decreased when using $\mathrm{NH}_{4} \mathrm{HCO}_{3}$ compared with $\mathrm{HCOOH}$. They probably prefer to deprotonate in basic mobile phase $(\mathrm{pH} \geq 8)$.

Second, we compared the ionization complex distribution of $5 \mathrm{hmC}$ using four additives to the mobile phase. The HPLC fractions of $5 \mathrm{hmC}$ were directly scanned from $\mathrm{m} / z 100$ to 300 under the positive ionization mode by an ESI-triple quadrupole mass spectrometer. $\mathrm{HCOOH}, \mathrm{HCOONH}_{4}$, or $\mathrm{CH}_{3} \mathrm{COONH}_{4}$ as the mobile-phase additive promotes $5 \mathrm{hmC}$ to form abundant $[5 \mathrm{hmC}+\mathrm{Na}]^{+}$and $[5 \mathrm{hmC}+\mathrm{K}]^{+}$complexes. Using normalizing intensity of $[5 \mathrm{hmC}+\mathrm{H}]^{+}$as 1.0 , the relative abundance of metal-5hmC complexes is about $19.1 \%$ to $202.9 \%$ (Figure 2 ). Interestingly, when using $\mathrm{NH}_{4} \mathrm{HCO}_{3}$ as the additive to the mobile phase, neither the $[5 \mathrm{hmC}+\mathrm{Na}]^{+}$nor the $[5 \mathrm{hmC}+\mathrm{K}]^{+}$ complex forms (Figure 2). These data suggest that $\mathrm{NH}_{4} \mathrm{HCO}_{3}$ partially improves the ionization efficiency of $5 \mathrm{hmC}$ by suppressing the formation of metal-5hmC complexes during the ESI process.

Optimization of SPE Columns. There are more than 3000 chemicals found in human urine, and the 4 most abundant 
Table 1. Precision of the HPLC-MS/MS Method

\begin{tabular}{|c|c|c|c|c|}
\hline \multirow[b]{2}{*}{ urine sample } & \multicolumn{2}{|c|}{ interday mean $\pm \mathrm{SD}, \mathrm{nM}(\mathrm{RSD}, \%)$} & \multicolumn{2}{|c|}{ intraday mean $\pm \mathrm{SD}, \mathrm{nM}(\mathrm{RSD}, \%)$} \\
\hline & $5 \mathrm{hmC}$ & $5 \mathrm{mC}$ & $5 \mathrm{hmC}$ & $5 \mathrm{mC}$ \\
\hline no. 11 & $20.6 \pm 1.8(8.9)$ & $100.0 \pm 2.9(2.9)$ & $19.9 \pm 1.2(5.8)$ & $97.9 \pm 1.4(1.4)$ \\
\hline no. 12 & $10.9 \pm 0.7(6.8)$ & $4.8 \pm 0.5(10.6)$ & $10.3 \pm 0.3(3.2)$ & $4.3 \pm 0.1(2.7)$ \\
\hline no. 13 & $28.2 \pm 1.6(5.6)$ & $24.5 \pm 1.0(4.2)$ & $27.1 \pm 2.1(7.7)$ & $23.3 \pm 0.8(3.4)$ \\
\hline
\end{tabular}

ingredients are $\mathrm{Na}^{+}, \mathrm{Cl}^{-}, \mathrm{K}^{+}$, and urea, the levels of which range from 4.6 to $22.5 \mathrm{mM} / \mathrm{mM}$ creatinine. ${ }^{52}$ To avoid possible ionization source contamination and ion suppression caused by coexisting ingredients in urine, two types of SPE cartridges (C18 and HLB) were tested for the cleanup and enrichment of the target deoxynucleosides. We found that the $\mathrm{C} 18$ cartridges were unable to effectively adsorb $5 \mathrm{hmC}$ during cartridge washing by pure water, and approximately $95 \%$ of $5 \mathrm{hmC}$ and $5 \mathrm{hmU}$ were washed away (Figure $3 \mathrm{~A}$ ). In comparison, the HLB cartridges, filled with a water-wettable stationary phase mixed with the immobilized hydrophilic ligands and lipophilic ligands, show a much better performance in the separation and enrichment of all the targets from urine (Figure 3B). Less than $20 \% 5 \mathrm{hmC}$ is lost during washing with water, and most of $5 \mathrm{hmC}, 5 \mathrm{hmU}$, and $5 \mathrm{fC}$ are retained in the HLB cartridges until they are eluted with $10-30 \%$ methanol (Figure 3B). Of note, we could observe a matrix effect even when we used HLB cartridges to enrich $5 \mathrm{hmC}$ from urinary samples. The MS signals of $5 \mathrm{hmC}$ and $5 \mathrm{mC}$ enriched from urinary samples were repressed over 17 times and 2.7 times (data not shown), respectively. However, the accurate quantification of urinary $5 \mathrm{hmC}$ and $5 \mathrm{mC}$ is obtained by adding stable isotopic standards of [D3] $5 \mathrm{mC}$ and [D3] $5 \mathrm{hmC}$ in known amounts to the urinary samples.

Calibration Curves, Recovery, and Precision. Calibration curves were obtained according to Experimental Section. Excellent linearity for $5 \mathrm{hmC}(y$ (peak area ratio of $5 \mathrm{hmC}$ to $\left.\left[\mathrm{D}_{3}\right] 5 \mathrm{hmC}\right)=0.0152 \times($ concn $\left.\mathrm{nM})-0.0025\right)$ and $5 \mathrm{mC}(y$ (peak area ratio of $5 \mathrm{mC}$ to $\left.\left[\mathrm{D}_{3}\right] 5 \mathrm{mC}\right)=0.0347 \times($ concn $\mathrm{nM})$ +0.1329 ) was achieved in the concentration range from 2.0 to $64.0 \mathrm{nM}$ with the correlation coefficient of $R^{2} \geq 0.999$.

The recovery was measured by spiking human urine samples with known amounts of $5 \mathrm{hmC}$ and $5 \mathrm{mC}(10.0$ and $20.0 \mathrm{nM}$, final concentration). The estimated recovery is about $101.3 \pm$ $4.1 \%$ for $10 \mathrm{nM} \mathrm{5hmC,} 103.5 \pm 2.4 \%$ for $20 \mathrm{nM} \mathrm{5hmC,} 70.2 \pm$ $0.9 \%$ for $10 \mathrm{nM} 5 \mathrm{mC}$, and $89.9 \pm 0.6 \%$ for $20 \mathrm{nM} 5 \mathrm{mC}$.

Three urine samples (nos. 11-13) were used for evaluating the precision of the HPLC-MS/MS method, and the results are summarized in Table 1 . The interday precision values shown by relative standard deviations (RSD) vary from $2.9 \%$ to $10.6 \%$, and the intraday precision values vary from $1.4 \%$ to $7.7 \%$.

Given the presence of the matrix repression effect, the limits of detection (LODs, $\mathrm{S} / \mathrm{N} \geq 3$ ) are estimated to be 25 amol for $5 \mathrm{mC}$ and 250 amol for $5 \mathrm{hmC}$, and the limits of quantification (LOQs, $\mathrm{S} / \mathrm{N} \geq 10$ ) are $75 \mathrm{amol}$ for $5 \mathrm{mC}$ and 760 amol for $5 \mathrm{hmC}$. The detection sensitivity of $5 \mathrm{mC}$ and $5 \mathrm{hmC}$ was measured using the latest series of Agilent triple quadrupole mass spectrometers (G6495).

Identification and Quantification of $5 \mathrm{hmC}$ in Human Urine. By the developed off-line SPE-coupled stable isotope dilution HPLC-MS/MS method, we further examined $5 \mathrm{hmC}$ and the other DNA intermediates in human urine. We collected morning urine samples from 13 healthy volunteers. $5 \mathrm{mC}$ and $5 \mathrm{hmC}$ could be detected in all the collected urine samples (Table 2). However, 5fC, $5 \mathrm{caC}$, and $5 \mathrm{hmU}$ could not be
Table 2. Quantification of $5 \mathrm{hmC}$ and $5 \mathrm{mC}$ in Human Urine Samples

\begin{tabular}{llccc} 
sample & gender & $\begin{array}{c}5 \mathrm{hmC}(\mathrm{nM})(\mathrm{mean} \\
\pm \mathrm{SD})\end{array}$ & $\begin{array}{c}5 \mathrm{mC}(\mathrm{nM})(\text { mean } \\
\pm \mathrm{SD})\end{array}$ & $\begin{array}{c}5 \mathrm{hmC} \text { vs } \\
5 \mathrm{mC}\end{array}$ \\
1 & female & $51.4 \pm 3.2$ & $112.4 \pm 2.6$ & 0.46 \\
2 & male & $17.8 \pm 0.4$ & $19.0 \pm 0.2$ & 0.94 \\
3 & female & $36.9 \pm 1.7$ & $41.0 \pm 1.4$ & 0.90 \\
4 & female & $12.9 \pm 1.6$ & $41.4 \pm 2.1$ & 0.31 \\
5 & male & $16.0 \pm 1.9$ & $18.8 \pm 0.4$ & 0.85 \\
6 & female & $5.4 \pm 0.1$ & $1.2 \pm 0.2$ & 4.67 \\
7 & male & $17.9 \pm 0.7$ & $55.0 \pm 1.4$ & 0.32 \\
8 & male & $6.7 \pm 0.3$ & $4.6 \pm 0.1$ & 1.45 \\
9 & male & $35.7 \pm 1.8$ & $161.5 \pm 1.0$ & 0.22 \\
10 & female & $33.9 \pm 2.0$ & $97.0 \pm 1.4$ & 0.35 \\
11 & female & $20.6 \pm 1.8$ & $100.0 \pm 2.9$ & 0.21 \\
12 & female & $10.9 \pm 0.7$ & $4.8 \pm 0.5$ & 2.27 \\
13 & female & $28.2 \pm 1.6$ & $24.5 \pm 1.0$ & 1.15 \\
average & & $22.6 \pm 13.7$ & $52.4 \pm 50.2$ & 1.08 \\
\hline
\end{tabular}

detected in all the urine samples. This is reasonable since those undetectable DNA intermediates display an abundance 1 or 2 orders of magnitude lower than that of $5 \mathrm{hmC} .^{15,33,45}$

As shown in Figure 4A, the peak of $5 \mathrm{hmC}$ from human urine (no. 2) (2.7 min, blue line) completely overlaps that of the added internal stable isotope standard $\left(\left[\mathrm{D}_{3}\right] 5 \mathrm{hmC}\right)$. Consistent with the nonisotope $5 \mathrm{hmC}$ standard (Figure 4C), urinary $5 \mathrm{hmC}$ also generates a transition with the second highest abundance $(m / z 258 \rightarrow 124)$ (Figure 4B). Moreover, the signal ratio of the primary ion transition $(\mathrm{m} / z 258 \rightarrow 142)$ to the secondary transition $(\mathrm{m} / z 258 \rightarrow 124)$ for urinary $5 \mathrm{hmC}$ is almost the same as that of the nonisotope $5 \mathrm{hmC}$ standard ( $\sim 3.2$, evaluated by peak height). These results suggest that urinary $5 \mathrm{hmC}$ has the same chromatographic retention and the same MS fragmentation pattern as the $5 \mathrm{hmC}$ standard, consistently confirming the presence of $5 \mathrm{hmC}$ in human urine.

The measured concentration of $5 \mathrm{hmC}$ in human urine is about 5.4-51.4 nM, and the average concentration is about $22.6 \pm 13.7 \mathrm{nM}(n=13)$. The average concentration of $5 \mathrm{hmC}$ in male and female urine samples is about $18.8 \pm 10.5(n=5)$ and $25.0 \pm 15.5 \mathrm{nM}(n=8)$, respectively. There is no significant difference in $5 \mathrm{hmC}$ levels between male and female samples (student $t$ test, $p=0.45$ ).

To evaluate the metabolism activity of $5 \mathrm{hmC}$ in genomic DNA, $5 \mathrm{mC}$ as an intrinsic reference is detected and quantified in all urine samples. The average concentration is about $52.4 \pm$ $50.2 \mathrm{nM}(n=13)$. Considering the normal concentration of creatinine in adult human urine ( $>18$ years old) is about 10 $\mathrm{mM}^{52}$ the normalized value of $5 \mathrm{mC}$ in our urine samples is about $5.2 \pm 5.0 \mathrm{nmol} / \mathrm{mmol}$ creatinine, which is consistent with the previous work. ${ }^{42}$

Previous work reported that the level of $5 \mathrm{hmC}$ is much less than that of its precursor $5 \mathrm{mC}$ in mammalian tissues. ${ }^{18,32-34}$ In mouse tissues, the highest levels of $5 \mathrm{hmC}$ are found in genomic DNA from brain tissues, including cortex, brain stem, and 

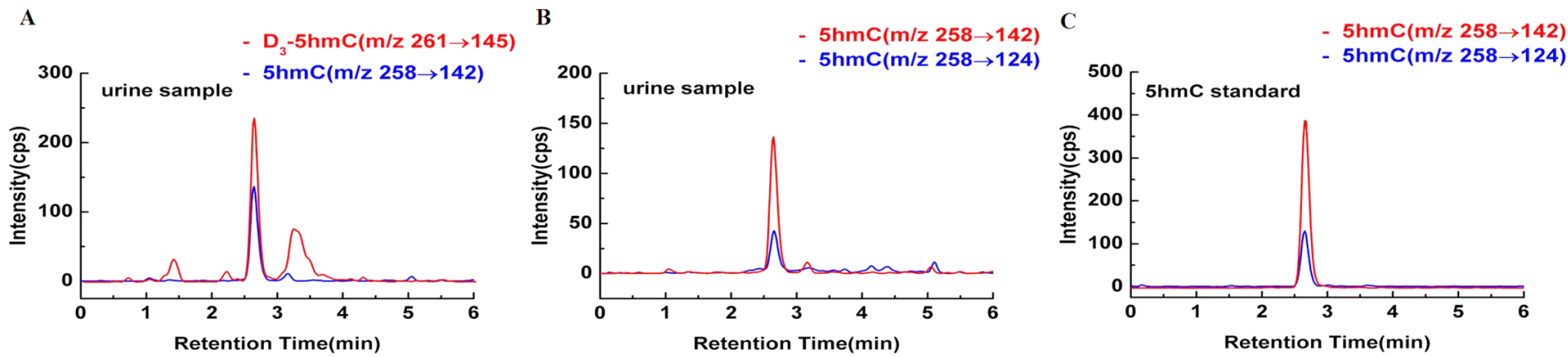

Figure 4. Identification of $5 \mathrm{hmC}$ in no. 2 urine sample by HPLC-MS/MS. Chromatograms of urinary $5 \mathrm{hmC}$ and $\left[\mathrm{D}_{3}\right] 5 \mathrm{hmC}$ (internal standard) are shown in A; the overlapped chromatograms for the two most intensive MRM transitions of $5 \mathrm{hmC}$ obtained from no. 2 urine samples and $5 \mathrm{hmC}$ standards are shown in B and C, respectively. The concentration of $5 \mathrm{hmC}$ standard used in $\mathrm{C}$ was $5 \mathrm{nM}$. The optimized method was used, and the details are described in Experimental Section.

cerebellum, ${ }^{32,33}$ and just account for $7.0-16.3 \%$ of $5 \mathrm{mC}$. In other mouse tissues, e.g., kidney, lung, heart, pancreas, liver, spleen, thymus, muscle, bladder, and testes, ${ }^{33,34}$ the level of $5 \mathrm{hmC}$ is relatively low and accounts for $0.7-3.7 \%$ of $5 \mathrm{mC}$. The average ratios of $5 \mathrm{hmC}$ vs $5 \mathrm{mC}$ in human tissues are also calculated: $2.9 \pm 0.8 \%$ for lung $(n=18)$ and $21.1 \pm 2.9 \%$ for brain $(n=6) .{ }^{18}$ Moreover, the ratios are much less in human lung $(1.4 \pm 0.4 \%, n=24)$ and brain tumors $(5.5 \pm 4.3 \%, n=$ 35). ${ }^{18}$

The molar concentration ratio of $5 \mathrm{hmC}$ to $5 \mathrm{mC}$ (from urinary samples) is about $0.21-4.67$ (Table 2). The level of $5 \mathrm{hmC}$ is even higher than that of $5 \mathrm{mC}$ in four samples (nos. 6, 8,12 , and 13), and the molar concentration ratio of $5 \mathrm{hmC}$ to $5 \mathrm{mC}$ is about 1.15-4.67. On average, the measured molar concentration ratio of $5 \mathrm{hmC}$ to $5 \mathrm{mC}$ is about 1.08. Compared with the ratio of tissue $5 \mathrm{hmC}$ to $5 \mathrm{mC}(0.007-0.16)$, the molar concentration ratio of $5 \mathrm{hmC}$ to $5 \mathrm{mC}$ in urine is astonishingly high $(0.21-4.67)$.

It is not known how and why $5 \mathrm{hmC}$ has a higher ratio in urine than in various tissues (in reference to $5 \mathrm{mC}$ ). If urinary $5 \mathrm{hmC}$ and $5 \mathrm{mC}$ result from genomic DNA metabolism, the observed higher ratio of $5 \mathrm{hmC}$ to $5 \mathrm{mC}$ may indicate that $5 \mathrm{hmC}$ has a more rapid turnover than $5 \mathrm{mC}$ in genomic DNA. Since $5 \mathrm{hmC}$ is linked to passive and active DNA demethylation, our observation probably suggests that DNA demethylation is an indispensible and important physiological process involved in the daily life of mammals and humans.

\section{CONCLUSIONS}

We developed an off-line SPE-stable isotope dilution HPLCMS/MS method for accurate quantification of $5 \mathrm{mC}$ and its iterative oxidation products $(5 \mathrm{hmC}, 5 \mathrm{fC}$, and $5 \mathrm{caC})$ and $5 \mathrm{hmU}$ in human urine. The use of $\mathrm{NH}_{4} \mathrm{HCO}_{3}$ significantly enhanced the ESI-MSMS detection of $5 \mathrm{mC}, 5 \mathrm{hmC}$ and $5 \mathrm{fC}$ by $1.8-14.3$ times. Even though all four deoxynucleosides ( $5 \mathrm{hmC}, 5 \mathrm{fC}$, $5 \mathrm{caC}$, and $5 \mathrm{hmU}$ ) are intermediates in DNA demethylation, only $5 \mathrm{hmC}$ could be detected in human urine. Unexpectedly, the molar ratio of $5 \mathrm{hmC}$ vs $5 \mathrm{mC}$ in urine is found to be much higher than that in genomic DNA of mammalian tissues, indicating more rapid turnover of $5 \mathrm{hmC}$ than $5 \mathrm{mC}$ in mammals.

\section{AUTHOR INFORMATION}

\section{Corresponding Author}

*Phone: 86-10-62849600. Fax: 86-10-62849600. E-mail: hlwang@rcees.ac.cn.

\section{Notes}

The authors declare no competing financial interest.

\section{ACKNOWLEDGMENTS}

This work was supported by grants from the Ministry of Science and Technology of China (2011YQ060084 to H.W.), the Ministry of Environmental Protection of China (201309045 to H.W.), the Strategic Priority Research Program of the Chinese Academy of Sciences (XBD14030200 and YSW2013A01 to H.W.), and the National Natural Science Foundation of China $(21327006,21435008$, and 21125523 to H.W.).

\section{REFERENCES}

(1) Bird, A. Genes Dev. 2002, 16, 6-21.

(2) Bird, A. P.; Wolffe, A. P. Cell 1999, 99, 451-454.

(3) Jaenisch, R.; Bird, A. Nat. Genet. 2003, 33, 245-254.

(4) Li, E.; Beard, C.; Jaenisch, R. Nature 1993, 366, 362-365.

(5) Panning, B.; Jaenisch, R. Genes Dev. 1996, 10, 1991-2002.

(6) Stancheva, I.; Hensey, C.; Meehan, R. R. EMBO J. 2001, 20, 1963-1973.

(7) Tahiliani, M.; Koh, K. P.; Shen, Y.; Pastor, W. A.; Bandukwala, H.; Brudno, Y.; Agarwal, S.; Iyer, L. M.; Liu, D. R.; Aravind, L.; Rao, A. Science 2009, 324, 930-935.

(8) Ito, S.; D’Alessio, A. C.; Taranova, O. V.; Hong, K.; Sowers, L. C.; Zhang, Y. Nature 2010, 466, 1129-1133.

(9) Nabel, C. S.; Kohli, R. M. Science 2011, 333, 1229-1230.

(10) Nawy, T. Nat. Methods 2013, 10, 466-466.

(11) Gao, Y.; Chen, J.; Li, K.; Wu, T.; Huang, B.; Liu, W.; Kou, X.; Zhang, Y.; Huang, H.; Jiang, Y.; Yao, C.; Liu, X.; Lu, Z.; Xu, Z.; Kang, L.; Chen, J.; Wang, H.; Cai, T.; Gao, S. Cell Stem Cell 2013, 12, 453469.

(12) Ficz, G.; Branco, M. R.; Seisenberger, S.; Santos, F.; Krueger, F.; Hore, T. A.; Marques, C. J.; Andrews, S.; Reik, W. Nature 2011, 473, 398-U589.

(13) Koh, K. P.; Yabuuchi, A.; Rao, S.; Huang, Y.; Cunniff, K.; Nardone, J.; Laiho, A.; Tahiliani, M.; Sommer, C. A.; Mostoslavsky, G.; Lahesmaa, R.; Orkin, S. H.; Rodig, S. J.; Daley, G. Q.; Rao, A. Cell Stem Cell 2011, 8, 200-213.

(14) Tan, L.; Shi, Y. G. Development 2012, 139, 1895-1902.

(15) Yin, R.; Mao, S.-Q.; Zhao, B.; Chong, Z.; Yang, Y.; Zhao, C.; Zhang, D.; Huang, H.; Gao, J.; Li, Z.; Jiao, Y.; Li, C.; Liu, S.; Wu, D.; Gu, W.; Yang, Y.-G.; Xu, G.-L.; Wang, H. J. Am. Chem. Soc. 2013, 135, 10396-10403.

(16) Zhao, B.; Yang, Y.; Wang, X.; Chong, Z.; Yin, R.; Song, S.-H.; Zhao, C.; Li, C.; Huang, H.; Sun, B.-F.; Wu, D.; Jin, K.-X.; Song, M.; Zhu, B.-Z.; Jiang, G.; Danielsen, J. M. R.; Xu, G.-L.; Yang, Y.-G.; Wang, H. Nucleic Acid Res. 2014, 42, 1593-1605. 
(17) Tellez-Plaza, M.; Tang, W.; Shang, Y.; Umans, J. G.; Francesconi, K. A.; Goessler, W.; Ledesma, M.; Leon, M.; Laclaustra, M.; Pollak, J. Environ. Health Perspect. 2014, 122, 946-954.

(18) Jin, S.-G.; Jiang, Y.; Qiu, R.; Rauch, T. A.; Wang, Y.; Schackert, G.; Krex, D.; Lu, Q.; Pfeifer, G. P. Cancer Res. 2011, 71, 7360-7365.

(19) Kraus, T. F. J.; Globisch, D.; Wagner, M.; Eigenbrod, S.; Widmann, D.; Muenzel, M.; Mueller, M.; Pfaffeneder, T.; Hackner, B.; Feiden, W.; Schueller, U.; Carell, T.; Kretzschmar, H. A. Int. J. Cancer 2012, 131, 1577-1590.

(20) Haffner, M. C.; Chaux, A.; Meeker, A. K.; Esopi, D. M.; Gerber, J.; Pellakuru, L. G.; Toubaji, A.; Argani, P.; Iacobuzio-Donahue, C.; Nelson, W. G.; Netto, G. J.; De Marzo, A. M.; Yegnasubramanian, S. Oncotarget 2011, 2, 627-637.

(21) Uchiyama, R.; Uhara, H.; Uchiyama, A.; Ogawa, E.; Takazawa, Y.; Ashida, A.; Koga, H.; Hayashi, K.; Kiniwa, Y.; Okuyama, R. J. Dermatol. Sci. 2014, 73, 161-163.

(22) Lian, C. G.; Xu, Y.; Ceol, C.; Wu, F.; Larson, A.; Dresser, K.; Xu, W.; Tan, L.; Hu, Y.; Zhan, Q.; Lee, C.-w.; Hu, D.; Lian, B. Q.; Kleffel, S.; Yang, Y.; Neiswender, J.; Khorasani, A. J.; Fang, R.; Lezcano, C.; Duncan, L. M.; Scolyer, R. A.; Thompson, J. F.; Kakavand, H.; Houvras, Y.; Zon, L. I.; Mihm, M. C., Jr.; Kaiser, U. B.; Schatton, T.; Woda, B. A.; Murphy, G. F.; Shi, Y. G. Cell 2012, 150, 1135-1146.

(23) Liu, C.; Liu, L.; Chen, X.; Shen, J.; Shan, J.; Xu, Y.; Yang, Z.; Wu, L.; Xia, F.; Bie, P.; Cui, Y.; Bian, X.-w.; Qian, C. PLoS One 2013, 8, e62828.

(24) Ko, M.; Huang, Y.; Jankowska, A. M.; Pape, U. J.; Tahiliani, M.; Bandukwala, H. S.; An, J.; Lamperti, E. D.; Koh, K. P.; Ganetzky, R.; Liu, X. S.; Aravind, L.; Agarwal, S.; Maciejewski, J. P.; Rao, A. Nature 2010, 468, 839-843.

(25) Yang, H.; Liu, Y.; Bai, F.; Zhang, J. Y.; Ma, S. H.; Liu, J.; Xu, Z. D.; Zhu, H. G.; Ling, Z. Q.; Ye, D.; Guan, K. L.; Xiong, Y. Oncogene 2013, 32, 663-669.

(26) Liu, X.; Zhang, G.; Yi, Y.; Xiao, L.; Pei, M.; Liu, S.; Luo, Y.; Zhong, H.; Xu, Y.; Zheng, W.; Shen, J. Leukemia Lymphoma 2013, 54, 2466-2473.

(27) Wang, F.; Yang, Y.; Lin, X.; Wang, J.-Q.; Wu, Y.-S.; Xie, W.; Wang, D.; Zhu, S.; Liao, Y.-Q.; Sun, Q.; Yang, Y.-G.; Luo, H.-R.; Guo, C.; Han, C.; Tang, T.-S. Hum. Mol. Genet. 2013, 22, 3641-3653.

(28) Sierksma, A. S. R.; Prickaerts, J.; Chouliaras, L.; Rostamian, S.; Delbroek, L.; Rutten, B. P. F.; Steinbusch, H. W. M.; van den Hove, D. L. A. Neurobiol. Aging 2013, 34, 319-337.

(29) Dong, E.; Gavin, D. P.; Chen, Y.; Davis, J. Transl. Psychiatry 2012, 2, e159.

(30) Kinney, S. M.; Chin, H. G.; Vaisvila, R.; Bitinaite, J.; Zheng, Y.; Esteve, P.-O.; Feng, S.; Stroud, H.; Jacobsen, S. E.; Pradhan, S. J. Biol. Chem. 2011, 286, 24685-24693.

(31) Nestor, C. E.; Ottaviano, R.; Reddington, J.; Sproul, D.; Reinhardt, D.; Dunican, D.; Katz, E.; Dixon, J. M.; Harrison, D. J.; Meehan, R. R. Genome Res. 2012, 22, 467-477.

(32) Muenzel, M.; Globisch, D.; Brueckl, T.; Wagner, M.; Welzmiller, V.; Michalakis, S.; Mueller, M.; Biel, M.; Carell, T. Angew. Chem., Int. Ed. 2010, 49, 5375-5377.

(33) Globisch, D.; Münzel, M.; Müller, M.; Michalakis, S.; Wagner, M.; Koch, S.; Brückl, T.; Biel, M.; Carell, T. PLoS One 2010, 5, e15367.

(34) Wu, H.; Zhang, Y. Genes Dev. 2011, 25, 2436-2452.

(35) Nagata, S. Annu. Rev. Immunol. 2005, 23, 853-875.

(36) Nagata, S.; Nagase, H.; Kawane, K.; Mukae, N.; Fukuyama, H. Cell Death Differ. 2003, 10, 108-116.

(37) Kawane, K.; Motani, K.; Nagata, S. Cold Spring Harbor Perspect. Biol. 2014, 6, doi: 10.1101/cshperspect.a016394.

(38) Itoh, K.; Aida, S.; Ishiwata, S.; Yamaguchi, T.; Ishida, N.; Mizugaki, M. Clin. Chim. Acta 1995, 234, 37-45.

(39) Zambonin, C. G.; Aresta, A.; Palmisano, F.; Specchia, G.; Liso, V. J. Pharm. Biomed. 1999, 21, 1045-1051.

(40) Lee, S. H.; Jung, B. H.; Kim, S. Y.; Chung, B. C. Rapid Commun. Mass Spectrom. 2004, 18, 973-977.

(41) Lee, S. H.; Kim, I.; Chung, B. C. Clin. Biochem. 2007, 40, 936938 .
(42) Hu, C.-W.; Liu, H.-H.; Li, Y.-J.; Chao, M.-R. Chem. Res. Toxicol. 2012, 25, 462-470.

(43) Kriaucionis, S.; Heintz, N. Science 2009, 324, 929-930.

(44) Li, W.; Liu, M. J. Nucleic Acids 2011, 870726-870726.

(45) Ito, S.; Shen, L.; Dai, Q.; Wu, S. C.; Collins, L. B.; Swenberg, J. A.; He, C.; Zhang, Y. Science 2011, 333, 1300-1303.

(46) Le, T.; Kim, K.-P.; Fan, G.; Faull, K. F. Anal. Biochem. 2011, 412, 203-209.

(47) Zhang, L.; Zhang, L.; Zhou, K.; Ye, X.; Zhang, J.; Xie, A.; Chen, L.; Kang, J. X.; Cai, C. J. Biomol. Screen. 2012, 17, 877-884.

(48) Chen, M. L.; Shen, F.; Huang, W.; Qi, J.-H.; Wang, Y.; Feng, Y. Q.; Liu, S.-M.; Yuan, B. F. Clin. Chem. 2013, 59, 824-832.

(49) Tang, Y.; Chu, J.-M.; Huang, W.; Xiong, J.; Xing, X. W.; Zhou, X.; Feng, Y. Q.; Yuan, B. F. Anal. Chem. 2013, 85, 6129-6135.

(50) Zhao, C.; Wang, H. Acta Chim. Sin. 2013, 71, 26-35.

(51) Yin, R.; Liu, S.; Zhao, C.; Lu, M.; Tang, M.-s.; Wang, H. Anal. Chem. 2013, 85, 3190-3197.

(52) Bouatra, S.; Aziat, F.; Mandal, R.; Guo, A. C.; Wilson, M. R.; Knox, C.; Bjorndahl, T. C.; Krishnamurthy, R.; Saleem, F.; Liu, P.; Dame, Z. T.; Poelzer, J.; Huynh, J.; Yallou, F. S.; Psychogios, N.; Dong, E.; Bogumil, R.; Roehring, C.; Wishart, D. S. PLoS One 2013, 8, e73076. 